ance of the term. Owing to the scarcity of employment in our vicinity, I then drifted over to the lumber woods of Michigan, where I remained two years at all kinds of work from skidding logs with an oxen team to running a sawmill engine. Returning home in the summer of 1868 I remained there until February 10, 1869, when I came to Des Moines and on the 14th entered the employ of the C. R. I. \& P. Ry. as fireman upon a locomotive and have been in the employ of that company since that time, serving forty years as a locomotive engineer.

In 1877 my home was in Stuart, Iowa, where we raised a company of the Iowa National Guard and I was elected captain. In 1878 I was elected major of the old Third regiment to which my company belonged, and in $1881 \mathrm{I}$ was elected lieutenant colonel of the Third regiment. I served in the National Guard under three governors-Newbold, Gear (two terms) and Sherman, in all nearly nine years.

\title{
MISSOURI'S NEW CONSTITUTION
}

The president of the Iowa Pioneer Lawmakers association for the current biennium, Israel A. Smith, was a member of the 1944 Constitutional convention that wrote a new constitution for the state of Missouri, which will be voted upon at a special state election there February 27, 1945.

Mr. Smith was chairman of the committee on public health and welfare, and a member of other important committees. He took an active part in preparing a thoroughly modern state constitution, which, among other things, is notable for being much shorter than the present one.

Mr. Smith was a member of the Iowa House of Representatives from Decatur county in the Thirty-fourth General Assembly, and in recent years has been living at Independence, Mo. His fine, scholarly attainments, and experience in legislation, no doubt served him well as a member of the Constitutional convention. 
Copyright of Annals of Iowa is the property of State of Iowa, by \& through the State Historical Society of Iowa and its content may not be copied or emailed to multiple sites or posted to a listserv without the copyright holder's express written permission. However, users may print, download, or email articles for individual use. 